\title{
GENETIC POLYMORPHISM OF PROPERDIN FACTOR B (BF) IN CHINESE PATIENTS WITH TWO TYPES OF DIABETES MELLITUS
}

\author{
Zhijung Luo, ${ }^{1}$ Chuanshu Du, ${ }^{1}$ Binjie Yu, ${ }^{2}$ \\ Yiquan LIANG, ${ }^{2}$ Katsushi TokunaGa, ${ }^{3}$ \\ and Keiichi Омото ${ }^{3}$ \\ ${ }^{1}$ Department of Medical Genetics, Sun Yat-sen University of Medical \\ Sciences, Guangzhou, China \\ ${ }^{2}$ Division of Endocrinology, First Affiliated Hospital, Sun Yat-sen \\ University of Medical Sciences, Guangzhou, China \\ ${ }^{3}$ Department of Anthropology, Faculty of Science, \\ The University of Tokyo, Tokyo 113, Japan
}

\begin{abstract}
Summary The distribution of phenotypes for properdin factor B (BF) has been investigated in 50 IDDM patients and 52 NIDDM patients living in Guangzhou, southern China, using high voltage agarose gel electrophoresis followed by immunofixation. A significant decrease in the frequency of $B F F$ positive patients $(p<0.01)$ and an increase in the gene frequency of $B F^{*} S(\mathrm{p}<0.005)$ were found in IDDM as compared to 259 normal controls. The relative risk for the BF F positive patients in IDDM was 0.15 . On the other hand, no significant association was observed between BF types and NIDDM.
\end{abstract}

\section{INTRODUCTION}

It is known that genetic factors play a predominant role in the pathogenesis of insulin dependent and non-insulin dependent diabetes mellitus (IDDM and NIDDM). Since the association between the HLA antigens and IDDM was found (Nerup et al., 1974), the interest has been extended to investigate the relationship between HLA-linked complement markers and IDDM. Certain alleles of factor $\mathrm{B}(\mathrm{BF})$, second component (C2), and fourth component (C4) have been shown to be associated with IDDM in Caucasoid populations (Raum et al., 1979; Kirk et al., 1980; de Mouzon et al., 1979; Bertrams et al., 1982). However, only a few reports have been published thus far on Mongoloid populations. The present paper is 
the first report concerning the distribution of BF phenotypes in Chinese patients with IDDM and NIDDM.

\section{MATERIALS AND METHODS}

Blood samples for BF typing were obtained from 50 IDDM and 52 NIDDM patients living in Guangzhou. All the patients have attented the Diabetic Clinic at the First Affiliated Hospital of Sun Yat-sen University of Medical Sciences. Samples for normal controls were obtained from 259 unrelated healthy persons attending routine antenatal clinic for genetic counselling at the same hospital. BF allotypes were examined using high voltage agarose gel electrophoresis and subsequent immunofixation according to Alper et al. (1972) with slight modifications (Tokunaga et al., 1982a).

\section{RESULTS AND DISCUSSION}

The results of BF typing in the IDDM and NIDDM patients and in the controls are shown in Table 1. Both in the IDDM and NIDDM groups the observed numbers of phenotypes were in agreement with those expected on the HardyWeindberg's law $(p>0.3)$. A significant decrease in the frequency of BF F positive patients was found in IDDM when compared with controls $\left(\chi_{\mathrm{x}}{ }^{2}=7.17, \mathrm{p}<0.01\right)$. Corresponding to the decrease, significant differences in the gene frequencies of $B F^{*} S$ and $B F^{*} F$ between IDDM patients and controls were also observed ( $\mathrm{p}<$ 0.005 ). The relative risk for $B F F$ positive individuals was calculated to be 0.15 . In NIDDM patients, in contrast, no association with BF types was found.

The significantly increased frequencies of BF F1 and/or S07 (S1) in the patients with IDDM have been reported in many Caucasoid populations (Raum et al., 1979; Kirk et al., 1979b; Bertrams et al., 1979a; Deschamps et al., 1979; de Mouzon et al., 1979). An increased frequency of BF F1 and a decreased frequency of BF F were also observed in American Negroid (Budowle et al., 1982). Moreover, a strong age relationship in the association of BF F1 with IDDM has been found. The BF F1 was significantly associated with the early-onset IDDM (Kirk et al.,

Table 1. BF types and allele frequencies in Chinese diabetics and normal controls.

\begin{tabular}{|c|c|c|c|c|c|c|c|c|c|}
\hline & \multirow{2}{*}{$\begin{array}{l}\text { No. } \\
\text { tested }\end{array}$} & \multicolumn{4}{|c|}{ BF types No. $(\%)$} & \multicolumn{4}{|c|}{ Allele frequencies } \\
\hline & & & $S+v e$ & $\mathrm{~F}+\mathrm{ve}$ & $\mathrm{S} 07+\mathrm{ve}$ & $B F^{*} S$ & $B F^{*} F$ & $B F^{*} S 07$ & Others \\
\hline IDDM & 50 & 50 & $(100.0)$ & $2(4.0)^{2}$ & $0(0.0)$ & $.980^{\mathrm{b}}$ & $.020^{\mathrm{c}}$ & .000 & .000 \\
\hline NIDDM & 52 & 52 & $(100.0)$ & $11(21.2)$ & $0(0.0)$ & .894 & .106 & .000 & .000 \\
\hline Controls & 259 & 252 & $(97.3)$ & $55(21.2)$ & $4(1.5)$ & .867 & .120 & .008 & .005 \\
\hline
\end{tabular}

${ }^{\mathrm{a}} \mathrm{p}<0.01, \mathrm{~b} \mathrm{p}<0.005,{ }^{\mathrm{c}} \mathrm{p}<0.005$. 
1979a; Barbosa et al., 1979; Bertrams et al., 1979b). A similar conclusion was obtained in a combined analysis using data on several Caucasoid populations (Budowle et al., 1983).

As for Asian populations, a positive association between a rare variant BF FT (F075) and IDDM was suggested in the Japanese population (Tokunaga et al., 1981, 1982b). A strong association between BF S07 and IDDM was reported in north India (Kirk et al., 1982), while in south India BF F was strongly associated with IDDM (Kirk et al., 1983).

We found no BF S07 positive diabetics in the present study, although four individuals out of 259 normal controls were S07 positive. On the other hand, the frequency of BF $F$ positive IDDM patients was significantly decreased. These differences in the BF-IDDM associations among various ethnic groups may reflect the differences in the linkage disequilibria between BF alleles and the suscepibility gene(s) to IDDM.

As we expected, there was no difference in the distribution of BF types between NIDDM patients and normal controls, which again demonstrates genetic heterogeneity of diabetes mellitus.

\section{REFERENCES}

Alper, C.A., Boenisch, T., and Watson, L. 1972. Genetic polymorphism in human glycine-rich beta-glycoprotein. J. Exp. Med. 135: 68-80.

Barbosa, J., Weitkamp, L., Guttormen, S., Johnson, S., and Szalapski, E., Jr. 1979. Bf in earlyonset insulin-dependent diabetes. Lancet II: 1239-1240.

Bertrams, J.E., Bauer, M.P., Gruneklee, D., and Gries, F.A. 1979a. Association of Bf F1, HLAB18, and insulin-dependent diabetes mellitus. Lancet II: 98.

Bertrams, J., Sodemann, P., Gruneklee, D., and Gries, F.A. 1979b. Bf in early-onset insulindependent diabetes. Lancet II : 1240.

Bertrams, J., Hintzen, U., Schlicht, V., and Schoeps, S. 1982. C4: Another marker for Type 1 diabetes. Lancet $\mathbf{I}: 41$.

Budowle, B., Reitnauer, P.J., Barger, B., Go, R., Roseman, J.M., and Acton, R.T. 1982. Properdin factor B in black Type I (insulin-dependent) diabetic patients. Diabetalogia 22: 483-485.

Budowle, B., William, C., Barger, B., Go, R., Roseman, J.M., and Acton, R.T. 1983. Age at onset of insulin-dependent diabetes mellitus associated with BF F1. Immunogenetics 17: 437-440.

de Mouzon, A., Ohayon, E., Ducos, J., and Hauptmann, G. 1979. Bf and C4 markers for insulindependent diabetes in Basques. Lancet II: 1364.

Deschamps, I., Lestradet, H., Marcelli-Barge, A., Benajam, A., Busson, M., Hors, J., and Dausset, J. 1979. Properdin factor B alleles as marker for insulin-dependent diabetes. Lancet II: 793.

Kirk, R.L., Serjeantson, S.W., Theophilus, J., Zimmet, P., Whitehouse, S., and Court, J.M. 1979a. Age relationship between insulin-dependent diabetes and rare alleles of properdin factor $\mathbf{B}$. Lancet II: 537.

Kirk, R.L., Theophilus, J., Whitehouse, S., Court, J., and Zimmet, P. 1979b. Genetic susceptibility to diabetes mellitus: The distribution of properdin factor B (Bf) and glyoxalase (GLO) phenotypes. Diabetes 28: 949-951.

Kirk, R.L., Ranford, P.R., Court, J., and Zimmet, P. 1980. Distribution of complement C2 and C6 types in Australian cases of diabetes mellitus. Med. J. Aust. II : 614-615. 
Kirk, R.L., Ranford, P.R., Theophilus, J., Ahuja, M.M.S., Mehra, N.K., and Vaidya, M.C. 1982. The rare factor Bf $\mathbf{S} 1$ of the properdin system strongly associated with insulin-dependent diabetes in north India. Tissue Antigens 20: 303-304.

Kirk, R.L., Ranford, P.R., Viswanathan, M., Mohan, V., Ramachandran, A., Snehalatha, C., Munirathnam Chetty, S.M., and John, L. 1983. Another association between the properdin system (BF) and insulin-dependent diabetes in south India. Tissue Antigens 22: 170-171.

Nerup, J., Platz, P., Anderson, O.O., Christy, M., Lyngsoe, J., Poulsen, J.E., Ryder, L.P., Nielsen, L.S., Thomsen, M., and Svejgaard, A. 1974. HL-A antigens and diabetes mellitus. Lancet II: 864-866.

Raum, D., Alper, C.A., Stein, R., and Gabby, K.H. 1979. Genetic marker for insulin-dependent diabetes mellitus. Lancet I: 1208-1210.

Tokunaga, K., Omoto, K., Maeda, H., Juji, T., Ishiba, S., and Maruyama, H. 1981. Bf and C2 polymorphism in Japanese patients with junevile-onset diabetes mellitus: Existence of a variant Bf allele. Tissue Antigens $18: 365-368$.

Tokunaga, K., Araki, C., Juji, T., and Omoto, K. 1982a. Polymorphism of properdin factor B in Japanese. Description of a rare variant and data of association with HLA and C2. Hum. Genet. 60: 42-45.

Tokunaga, K., Omoto, K., Juji, T., and Itoh, T. 1982b. Polymorphism of BF, C2 and GLO in Japanese patients with insulin-dependent diabetes mellitus: Confirmation of an increase of $B F^{*} F T$. Hum. Genet. 62: 86-88. 